\title{
The Norms of Address Terms in Arabic: The Case of Saudi Speech Community
}

\author{
Aied Alenizi ${ }^{1}$ \\ ${ }^{1}$ Department of English, College of Education, Majmaah University, Majmaah, Saudi Arabia \\ Correspondence: Department of English, College of Education, Majmaah University, Majmaah 11952, Saudi \\ Arabia. E-mail: a.alenizi@mu.edu.sa
}

Received: May 23, 2019 Accepted: June 20, 2019 Online Published: August 26, 2019

doi:10.5539/ijel.v9n5p227 URL: https://doi.org/10.5539/ijel.v9n5p227

\begin{abstract}
This paper investigates the address norms used in the Saudi Arabic speech community. The study examines address term usage in five different contexts: family, neighbors, workplace, school and strangers. The study seeks answers for two questions: (1) What address forms do Saudi Arabic speakers use to address each other? (2) What factors cause a difference in use of one term over another? Responses were collected from 40 Saudi speakers of Arabic who were divided evenly based on age and gender. The findings reveal nine key categories as fundamental techniques used by Saudi Arabic speakers to address one another including first names, teknonyms, common names, kin terms, kin term along with first name, terms of endearment, titles, occupation and address by gender (boy/girl). Social factors like age, gender, socio-economic status, level of formality as well as degree of intimacy and occupation were also essential in determining form usage.
\end{abstract}

Keywords: pragmatics, sociolinguistics, address terms, politeness, speech community, formality

\section{Introduction}

Understanding how people start conversations or address each other in a particular language is a crucial to studying the ways that communication strengthens the ties between individuals. Address terms are considered an important channel in displaying social information. The present paper explores address behaviors in Saudi Arabic. Reviewing the literature, the bulk of empirical studies on terms of address primarily focus on Anglo-American, Asian and Latin American contexts with very little study of Arabic speech communities. There are rules and social factors that govern address term usage (Mehrotra, 1981). Thus, different speech communities may use different terms of address and social factors influencing one speech community may not have the same influence in other speech communities. Arabic language is spoken in 21 countries and the norms and traditions differ from one country to another. Therefore, how the terms of address are used differs from one country to another. For example, in Saudi Arabia, it is not uncommon to use 'father/mother of (name of his/her first son/daughter)' whereas this term is considered odd in Libya, Tunisia, and Algeria.

Accordingly, this paper examines a range of address terms used by Saudi Arabic speakers in and sheds light on the social factors that influence these choices. The study also seeks to answer the following questions: (1) What address forms do Saudi Arabic speakers use to address each other? (2) What factors inform a difference in use of one term over another?

This study takes its significance from Afful's claim (2006, p. 267): "different speech communities are likely to be different, since different languages have different linguistic resources to express what is culturally permissible and meaningful." In addition, Dickey and Bain (1998) point out that address terms are crucial to ordinary people citing examples that explain the importance of the proper use of address terms: a fine of 2.225 DM was issued to a German lady who mistakenly "addressed a policeman as $d u$ instead of Sie," and a German bus driver was given a ticket of $100 \mathrm{DM}$ for addressing a Turkish student with $d u$.

\section{Overview of Address Terms}

Address terms are words and expressions for addressing individuals or groups. Researchers have proposed different definitions. For instance, Yule (2006) defines address terms "as words or phrases used to label the person being talked to or written about." Furthermore, Keshavarz (2001) asserts that address terms are linguistic forms used to attract others' attention or to refer to them in a conversation. Oyetade (1995) defines address terms 
"as words or phrases used in shared, dyadic and face-to-face situations to designate the person being talked to" in the course of conversation.

According to Braun (1988, p. 7), forms-of-address might have different functions rather than designating the addressee. They can be used as conversation initiators. However, some are merely frequently used expressions such as "Hey!" or "Excuse me!" in English. This type of expression exists in the data elicited for this study and are considered because they function to get the addressee attention rather than referring to a person in particular.

Braun (1988) asserts that address terms often involve three word-classes: nouns, pronouns and inflected-verbs. Following is his categorized list of the most common nouns of address:

1) Names: All languages use nouns to refer to human and non-human objects. Names could have diverse functions as an address. In Saudi Arabic, for instance, first names, but not family names, are used as address forms.

2) Forms-of-address that correspond to the English /Mr.//Mrs./ /Madam/: In Arabic, for example, the equivalent for Mr. is 'al-sayed' and for Mrs. 'alsayedah.'

3) Kin terms: Refer to forms that indicate blood relations but may also be used when not blood related based on specific context and function.

4) Titles: Although there is no agreement on title, Braun (1988) points out that title is preferred when acquired through appointment (e.g., doctor, engineer etc.) or inherited (e.g., Count in English and Shaikh in Arabic).

5) Abstract nouns: Address forms that refer to an abstract feature of the addressee such as (Your) Excellency, (Your) Grace, (Your) Honor.

6) Job-related: Forms that describe addressee's profession or function such as driver, waiter in English and Ostath, Moaalim "teacher" in Arabic.

7) Words that designate the relationship type: For example, in Arabic 'Jarri, Sadiqi' are used to address a neighbor and friend respectively. However, these types of terms may have extended functions that do not necessarily correspond to the actual relationship (Braun, 1988).

8) Terms of endearment: Functions are determined by context and relations rather than semantic characteristics and based on user's creativity and imagination.

9) Teknonyms: Define the addressee based on relationship to someone else (father of, son of, mother of etc.).

\section{Literature Review}

The work of Brown and Gilman (1960) and Brown and Ford (1961) act as a model for a large number of studies dealing with address terms in different speech communities (Al-Khalib, 2003; Alrabaa, 1985; Braun, 1988; Dickey, 1996; Geertz, 1972; Lambert \& Tucker, 1976; Parkinson, 1985; Sanda, 1993) and are frequently cited as necessary for all work on address terms.

Brown and Gilman (1960) addressed the use of second person pronouns $t u$ 'singular you' and vous 'plural you' in French and its equivalent in some other European languages such as German and Spanish. They point out that the norms for pronoun selection are the same for address in first name only, title and family name in English. The "power factor" is of crucial importance in determining pronoun use. That is, the person with superiority is likely to use $t u$ and receives the differential Vous from the addressee with no or less power. The other factor that has a role in pronoun selection is solidarity. Solidarity is mutual since its invocation is seen among peers, friends or people intimately related. That is, the pronoun $t u$ is reciprocally used by participants. The authors claimed that the use of address pronouns changes over time depending on the circumstances of the speech community, and the solidarity rule may extend to include everyone.

Much research has been conducted on terms of address in relation to English and other European languages (Wardhaught, 1992; Dickey \& Bain, 1998; Ervin-Tripp, 1972; Lambert \& Tucker, 1976; Moles, 1974; Parkinson, 1985). Dickey and Bain (1998), for example, indicate that there exists a bias in studying English and other European languages and states the importance of investigating other languages like Arabic, Korean, and Polish due to the possible unexpected results.

Parkinson's study (1985) is traced as one the earliest to examine address term usage in Arabic speaking communities, specifically the Egyptian speech community. He built his study on naturally occurring data elicited from different speech events in different settings. The study did not focus only on the linguistic structure of address of the investigated issue but also viewed it from a sociolinguistic viewpoint. Parkinson's work supported the idea that address term usage is determined on the basis of power and solidarity factors (Brown \& Gilman, 
1960).

Farghal and Shakir (1994) address the nature of relational social honorifics in the Jordanian speech community and focus on kin-terms as well as titles of address that designate distance and affection. To elaborate, distant honorifics are used to address strangers whereas affectionate terms address relatives, friends and, sometimes, strangers. Jureidini and Maclaurin (1984) note that the heavy use of kin terms in Jordanian communities can be attributed to social life in these communities centered around family and relationships between family members.

Al Khatib (2003) also investigates the address system in Jordanian Arabic and provides a thorough description of address norms in Jordanian society. The findings prove that the usage of address terms in JA is not random, but rather functional and rule-governed based on a number of social factors including social distance, socio-economic status, gender, age and occupation. The study followed Brown and Gilman's (1960) solidarity and power approach supplemented by Brown and Levinson's (1987) face theory. The author claims that the improper use of address terms tend to threaten the addressee's face and demonstrates that the patterns of address terms may function as supporting politeness when they interact with politeness techniques. He also asserts that the norms of address terms are undergoing a serious change due to the influence and borrowing of terms from foreign languages such as English, French and Turkish.

Braun (1988) investigates address terms utilized by children to address their parents in Jordanian society and demonstrates that they sometimes use formal terms to address their parents to show respectfulness. For instance, they utilize terms such as hadretak and hadritik instead of using the second person pronoun anta and anti. Other terms such as hajj and hajjah may also be used to address elderly members of the family and strangers as well. Such term employment highlights the speaker's social position and relation ties between interlocutors (Yassin, 1978).

\section{The Study}

Reviewing the literature, much work has been done on address terms in different speech communities. However, Arabic speech communities suffer from scarcity of literature addressing the issue of the use of address terms. There are a handful of works conducted on Jordanian, Egyptian and Kuwaiti speech communities, but none deal with terms of address in Saudi Arabia.

Hence, this descriptive study specifically deals with address terms in the Saudi speech community. This paper aims at providing a description of address norms in the Saudi society in relation to the social contexts in which they are employed. It is hypothesized that the use of address terms in Saudi Arabic is constrained by function, structure and rules. The study also investigates the role of social factors such as social distance, socio-economic status, occupation, age and gender in the use of address terms.

\section{Method}

\subsection{Participants}

A questionnaire was administered to 40 Saudi adult participants divided evenly into males and females (20 males and 20 females). The participants, varied in age and each group, were split into two age windows: younger than and older than 30 years old. The youngest participant was 21 and the eldest was 60 years old. The researcher followed convenience sampling to gain access to a reliable number of participants and because generalization of the results was not the goal of the study. Fourteen of the participants were students in the United States who claimed to speak Najdi dialect (a dialect spoken at the central part of Saudi Arabia. Most of them work as teachers at university level, so they are likely to belong to the middle-class. The other 26 participants resided in the central province of Saudi Arabia where Najdi dialect is mainly spoken. This group may be viewed as middle class as all of them hold a job and live a stable economic life.

\subsection{Instrument}

The questionnaire, adopted from (Braun, 1988) with some modifications, consists of two parts. In the first part, the participants have to provide personal information about the dialects they speak, age and occupation to make the task of categorization possible. The second part consists of five sections: family, neighbors, school, workplace and unknown addresses. In each of these sections, the participants were asked to provide how they address people and are addressed by the same people. The questionnaire is provided in the appendix.

\subsection{Data Collection}

The researcher distributed the questionnaire to his classmates, friends and speakers of Saudi Arabic in Muncie community, United States. More responses were gathered from Saudi Arabia by the researcher's male and female assisters living there and who were trained and instructed by the researcher (i.e., assisters differ in gender due to 
gender segregation in Saudi Arabia). The male was responsible for administrating the questionnaire to his friends and fellow workers and neighbors. The female, on the other hand, was responsible for distributing the questionnaire to her female classmates, friends, teachers and neighbors. After they had collected the data, they scanned the questionnaires and emailed them to the researcher.

\section{Results and Discussion}

The results of this study reveal that Saudi Arabic speakers use a huge variety of address terms. The contexts of these terms vary. Some of these terms are used only among family members and some of them are common in other contexts. In determining the use of certain terms instead of others, the speaker's and addressee's age and gender sometimes play a key role. The use of certain terms may or may not be reciprocal depending on the relationship between the speaker and addressee. In what follows, address term usage is analyzed in each context.

\subsection{Address Terms Among Family Members}

Family in Saudi society is one of the most fundamental social institutions and is considered the primary source for individual identity and status. The structure of the family tends to be patriarchal implying that the father in the family appears to be authoritative and the most respected family member. Address term usage among family members differs from address terms in other contexts. Traditionally, Saudi people tend to address each other by using first names. First names in Saudi society are unique and meaningful in that they usually stem from the surrounding environment. First names in Saudi society are not an uncommon type of address term.

Table 1. Percentages/frequencies of address term usage among family members.

\begin{tabular}{llllll}
\hline TOA & $\mathrm{M}+30$ & $\mathrm{M}-30$ & $\mathrm{~F}+30$ & $\mathrm{~F}-30$ & Total (40/100) \\
$\mathrm{N}=10$ & 10 & 10 & 10 & 10 & 40 \\
\hline First Name & 10 & 10 & 10 & 10 & $40(100)$ \\
Teknonyms & 5 & 5 & 3 & 1 & $14(35)$ \\
Kin term & 10 & 10 & 10 & 10 & $40(100)$ \\
Kin + Name & 0 & 2 & 0 & 5 & $6(15)$ \\
Praise name & 4 & 3 & 5 & 6 & $18(45)$ \\
Endearment & 4 & 2 & 3 & 1 & $10(25)$ \\
Title & 0 & 0 & 0 & 0 & $0(0)$ \\
\hline
\end{tabular}

Note: $\mathrm{TOA}=$ address terms, $\mathrm{N}=$ Number of participants in each group.

Table 1 shows that all participants used first names to address other family members (100\%) making first names the most common norm used in a family context. The exchange of first names among family members is subjected to strict social rules. The reciprocal and non-reciprocal use of first names is determined by intimacy, age and gender. The role of age in the fabric of the family determines kin term usage to address parents. The reciprocal use of first names is usually the norm among brothers and sisters. Table 1 also shows that Teknonyms are also used among family members $(35 \%)$. Parkinson $(1985$, p. 58) states that teknonymic custom is deeply rooted in Arabic culture wherein "great value is ascribed to the act of producing sons". The structure of this type is to use the name of the person's first son or daughter to address him (i.e., father of Ali, mother of Ali). In some cases, the addressee may receive teknonyms consisting of father of plus person's father's name since the Saudi societal tradition is to name the son after his grandfather and the daughter after her grandmother. This type of address term usage shows respect to the addressee. In most cases, the younger family members address older members by this term except parents and grandparents who are addressed by kin terms such as yubah 'father' yummah 'mother.' Kin terms are rarely used by brothers and sisters to address each other. In some cases, kin terms along with first names are used to address senior family members other than parents such as grandparents, uncles, and aunts. Kin terms are usually used to distinguish parents from grandparents. Some participants reported that they address their grandfather by yabah 'father', but to distinguish him from their real father, they add his first name such as 'yabah Mohammad'. Table 1 shows that the age of the speaker plays a role. That is, only participants younger than 30 years old use this norm of address and the number of family female members using this term is bigger than males.

Praise name, which is a name type derived from the person's first name, is also used among family members. The diminutive form of the first name is a very common example: Mohammad is called "Hamodi", and Fahad "Fahodi". Praise name usage shows a great deal of intimacy. All groups of participants use praise names. However, this is also governed by age constraint. It is often used by older family members to address younger members like sons, daughters, nieces, and nephews. The acceptance of these names is less common by older people even in a family context and even lesser outside. 
The data shows that terms of endearment or what can be called terms of intimacy are used among family members by all groups across gender and age. The most frequently used terms by the participants is alghaliah, 'the most valued,' or alhabibah, 'the beloved,' which are often used by sons or daughters to address their mothers. Ya Taweel al omer, 'who has a long life,' is used to address fathers or grandfathers.

\subsection{Address Terms with Neighbors}

Neighbors are essential components of Saudi social fabric. There is a proverb in Arabic that says, "Aljar qabl aldar," choose your neighbor before you choose your house. This indicates that neighbors are important and should be dealt with in a proper language. Table 2 below divides neighbors into two categories based on familiarity to other neighbors. Familiarity, along with age, influences address term usage between neighbors. If the neighbor is a close friend, it is common that he or she is addressed by first name when there is no age gap between the two speakers. It is also common to use Teknonyms to show more respect. However, if the difference in age between the speakers is great, the younger is likely to use either Teknonyms (e.g., Father of Ali) or a proper kin term such as $y a$ ?am 'uncle' to address the elder (also applies to females). In the case that the addressee is younger, he or she is likely to be addressed with kin terms (son, or daughter).

Table 2. Percentages/frequencies of address term usage with neighbors in two contexts: intimate vs. non-intimate neighbor.

\begin{tabular}{lllllllllll}
\hline TOA & \multicolumn{2}{l}{$\mathrm{M}+30$} & \multicolumn{2}{l}{$\mathrm{M}-30$} & \multicolumn{2}{l}{$\mathrm{F}+30$} & \multicolumn{2}{l}{$\mathrm{F}-30$} & \multicolumn{2}{l}{ Total 40 (100) } \\
& $\mathrm{i}$ & $\mathrm{n}$ & $\mathrm{i}$ & $\mathrm{n}$ & $\mathrm{i}$ & $\mathrm{n}$ & $\mathrm{i}$ & $\mathrm{n}$ & $\mathrm{i}$ & $\mathrm{n}$ \\
\hline First Name & 10 & 3 & 10 & 4 & 10 & 2 & 10 & 4 & $40(100)$ & $13(32.5)$ \\
Teknonyms & 10 & 4 & 9 & 6 & 8 & 8 & 5 & 2 & $32(80)$ & $20(50)$ \\
Kin term & 7 & 6 & 6 & 4 & 8 & 4 & 9 & 5 & $30(75)$ & $19(47.5)$ \\
Kin + Name & 0 & 0 & 1 & 0 & 0 & 0 & 0 & 0 & $1(2.5)$ & $0(0)$ \\
Praise name & 0 & 0 & 1 & 0 & 0 & 0 & 1 & 0 & $2(5)$ & $0(0)$ \\
Endearment & 0 & 4 & 0 & 4 & 0 & 0 & 1 & 1 & $1(2.5)$ & $9(22.5)$ \\
Boy/girl & 0 & 0 & 0 & 0 & 6 & 2 & 0 & 0 & $6(15)$ & 0 \\
Title & 0 & 1 & 0 & 1 & 0 & 0 & 0 & 0 & 0 & $2(5)$ \\
\hline
\end{tabular}

Note: $\mathrm{i}=$ intimate neighbor, $\mathrm{n}=$ non-intimate neighbor.

On the other hand, in the case of the neighbor being new or when the relationship between the neighbors is formal (non-intimate), other address norms are employed. The use of the first name with an unfamiliar neighbor is limited to cases where the interlocutors are young and of the same age window. The percentage of first name usage to address a strange or new neighbor is significantly less than first name usage for a close friend neighbor $(32.5 \%$ vs. $100 \%)$. This holds true across participant gender and age groups. When the relationships are not yet strong, speakers tend to use proper address terms such as kin terms (?ax 'brother,' uxt 'sister' ?am 'uncle'). The table also shows that men tend to use more terms of endearment than women such as yalHabib, 'beloved,' and ya alTaib, 'generous.' These terms express formality, may also show solidarity, and help strengthen the ties between speaker and addressee. The data shows that only females who are more than 30 years old use address terms such as boy and girl with both neighbors if the addressees are young.

\subsection{Address Terms in School}

Saudi Arabic speakers display various address norms in school settings. Particular term usage is determined by the degree of familiarity and social hierarchy between the speaker and addressee. Fellow students address each other differently from addressing lecturers and professors. Table 3 illustrates the difference in using address terms if the fellow student's name is known or unknown.

Table 3. Percentages/frequencies of address terms usage among known and unknown fellow students.

\begin{tabular}{llllllllllll}
\hline TOA & \multicolumn{1}{c}{$\mathrm{M}+30$} & \multicolumn{2}{c}{$\mathrm{M}-30$} & \multicolumn{2}{c}{$\mathrm{F}+30$} & \multicolumn{2}{c}{$\mathrm{F}-30$} & \multicolumn{2}{c}{ Total 40 (100) } \\
& $\mathrm{n}$ & $\mathrm{a}$ & $\mathrm{n}$ & $\mathrm{a}$ & $\mathrm{n}$ & $\mathrm{a}$ & $\mathrm{n}$ & $\mathrm{a}$ & $\mathrm{n}$ & $\mathrm{a}$ \\
\hline First Name & 7 & 0 & 10 & 0 & 10 & 0 & 10 & 0 & $37(92.5)$ & 0 \\
Teknonyms & 6 & 0 & 3 & 0 & 2 & 0 & 0 & 0 & $11(27.5)$ & 0 \\
Kin term & 0 & 2 & 0 & 2 & 0 & 1 & 0 & 2 & 0 & $7(17.5)$ \\
Endearment & 0 & 3 & 0 & 4 & 0 & 2 & 0 & 1 & 0 & $10(25)$ \\
Title & 0 & 3 & 0 & 1 & 0 & 1 & 0 & 0 & 0 & $5(12.5)$ \\
Boy/girl & 0 & 2 & 0 & 0 & 0 & 3 & 1 & 2 & $1(2.5)$ & $7(17.5)$ \\
\hline
\end{tabular}


The first name is the most common address term used among familiar fellow students by all participants (92.5\%). The second common address term used by fellow students is Teknonyms (27.5\%). Notice that 6 participants of age group $(\mathrm{M}+30)$ report that they use first name, whereas participants belonging to the younger group (M-30) used it in a lesser degree. Because students of this age (i.e., above 30 years old) are expected to be married and have children, they exchange Teknonyms to show respect. Female participants are less likely to use this technique to address each other.

However, if the name of the fellow student is unknown, other address norms are followed. A kin term is one way to address someone whose name is unknown and s/he belongs to the speaker's age window, such as ?ax, 'brother,' ?uxt, 'sister.' Terms of endearment are also used to address an unknown person, such as ya aTayib, 'generous.'

Another remarkable observation in this context is that in some cases the speaker attempts to address people with boy/girl address forms. The data reveals that $17.5 \%$ use such terms. One noteworthy finding to highlight is that most of the participants across groups avoid the use of address terms in addressing unknown fellow students by other techniques. They, for instance, use attention-grabbers such as lao samaHT, 'excuse me' or hey!

Table 4. Percentages/frequencies of address terms usage with instructors and professors in the classroom

\begin{tabular}{|c|c|c|c|c|c|c|c|c|c|c|}
\hline \multirow[t]{2}{*}{ TOA } & \multicolumn{2}{|c|}{$\mathrm{M}+30$} & \multicolumn{2}{|c|}{ M -30 } & \multicolumn{2}{|c|}{$F+30$} & \multicolumn{2}{|c|}{ F -30} & \multicolumn{2}{|c|}{ Total $40(100)$} \\
\hline & Instr & Prof & Instr & Prof & Instr & Prof & Instr & Prof & Instr & Prof \\
\hline First Name & 0 & 0 & 0 & 0 & 1 & 0 & 1 & 0 & $2(5)$ & 0 \\
\hline Teknonyms & 0 & 0 & 1 & 0 & 0 & 0 & 1 & 0 & $2(5)$ & 0 \\
\hline Kin term & 0 & 0 & 0 & 0 & 0 & 0 & 0 & 0 & 0 & 0 \\
\hline Endearment & 0 & 0 & 0 & 0 & 0 & 0 & 0 & 0 & 0 & 0 \\
\hline Doctor (+name) & 2 & 10 & 7 & 10 & 2 & 9 & 0 & 10 & $11(27.5)$ & $39(97.5)$ \\
\hline Ostath (+name) & 8 & 0 & 6 & 0 & 6 & 1 & 8 & 0 & $28(70)$ & $1(2.5)$ \\
\hline
\end{tabular}

Note: Instr $=$ instructor, prof $=$ professor.

Parkinson (1985, p. 119) defines occupation address terms as those earned for a degree or related to a particular job. Saudi Arabic speakers addressing lecturers and professors in school contexts display new address terms. The social hierarchy plays an important role in determining address terms. Obviously, teachers are higher status than students and are, thus, in a powerful and authoritative position. Therefore, the interaction between teachers and students in a classroom is greatly formal and requires that the powerless show respect to the powerful. Therefore, students are less likely to address their instructors and professors by their first names. Instead, they choose a proper title that corresponds to the addressee's qualifications. The students are likely to distinguish between a person who holds a $\mathrm{PhD}$ (i.e., s/he is called $\mathrm{Dr}$. X) and the person who holds a Master's degree or Bachelor's (i.e., $\mathrm{s} /$ he is called ostath, "instructor"). Notice that the percentage of those using the title "doctor" to address an instructor is $27.5 \%$. This is because some students want to show more respect to their teacher. However, the frequency of ostath reaches $28 \%$. It seems that there is no difference in terms of the gender and age of the speaker as the frequencies are quite close. There is an agreement $(97.5 \%)$ about the title 'doctor' to address a person with a $\mathrm{PhD}$.

Table 5. Percentages/frequencies of address terms used with instructors and professors outside school

\begin{tabular}{|c|c|c|c|c|c|c|c|c|c|c|}
\hline \multirow[t]{2}{*}{ TOA } & \multicolumn{2}{|c|}{$M+30$} & \multicolumn{2}{|c|}{ M -30 } & \multicolumn{2}{|c|}{$F+30$} & \multicolumn{2}{|l|}{ F -30} & \multicolumn{2}{|c|}{ Total 40 (100) } \\
\hline & $\underline{\text { Instr }}$ & prof & $\underline{\underline{\text { Instr }}}$ & prof & $\underline{\text { Instr }}$ & prof & Instr & prof & $\underline{\text { Instr }}$ & prof \\
\hline Personal Name & 3 & 1 & 3 & 0 & 2 & 0 & 3 & 1 & $11(27.5)$ & $2(5)$ \\
\hline Teknonyms & 3 & 1 & 2 & 3 & 0 & 0 & 1 & 0 & $6(15)$ & $4(10)$ \\
\hline Kin term & 0 & 0 & 0 & 0 & 0 & 0 & 0 & 0 & 0 & 0 \\
\hline Endearment & 0 & 0 & 0 & 0 & 0 & 0 & 0 & 0 & 0 & 0 \\
\hline Doctor (+name) & 1 & 8 & 4 & 7 & 2 & 8 & 0 & 9 & $7(17.5)$ & $32(80)$ \\
\hline Ostath (+name) & 3 & 0 & 7 & 0 & 4 & 2 & 7 & 0 & $21(52.5)$ & 0 \\
\hline
\end{tabular}

Note: Instr $=$ instructor, prof $=$ professor.

Address term usage between instructors and students seems to be governed by the settings of the interaction. Comparing the percentages in Table 4 with the percentages in Table 5, there is an increase in the use of first names among students when they address their instructors and professors outside school. Notice that the 
percentage of the use of instructors' first names increased from $5 \%$ in school to $11 \%$ outside school. By the same token, the first name uses to address professors increased from $0 \%$ in school to $5 \%$ outside school. This difference could be attributed to the degree of formality in the student to teacher relationship where in school context is more formal than outside school. This degree of formality between interlocutors led to the emergence of another address term students used to address their teachers. Students outside school seem to use Teknonyms to address their teachers. The data shows that $15 \%$ percent of the participants use Teknonyms to address their instructors and $10 \%$ use the same term to address their professors. Furthermore, there is a decrease in the percentage of title use outside school. It can be noted that students still maintain a respectful relationship with their teacher even though they employ different address terms. In other words, the use of titles shows respect in formal contexts whereas the use of Teknonyms also shows in informal situations. The use of first name as an address term is non-reciprocal for, in both formal and informal contexts, the teacher addresses their students with their first names. The degree of formality, however, influences the first name usage to address teachers.

\subsection{Address Terms in the Workplace}

Work related address terms exist in Saudi Arabic. The data analyzed in this section is related to the address terms used between workers in the workplace. Specifically, the relationship between workers is specified by being superior and inferior. Superior people find it appropriate to address those who are inferior by their first names. The percentage first name usage by a superior to address an inferior in the workplace reaches $92 \%$. It seems that the use of this term is non-reciprocal as only $25 \%$ of the participants reported their use of first names to address their superiors (See Table 6).

Table 6. Percentages/frequencies of instance of address terms usage at workplace

\begin{tabular}{lllllllllll}
\hline TOA & \multicolumn{3}{c}{$\mathrm{M}+30$} & \multicolumn{3}{c}{$\mathrm{M}-30$} & \multicolumn{3}{c}{$\mathrm{F}+30$} & \multicolumn{2}{c}{$\mathrm{F}-30$} & \multicolumn{2}{c}{ Total 40 (100) } \\
& sup & Inf & sup & Inf & sup & Inf & sup & Inf & sup & inf \\
\hline First Name & 2 & 9 & 4 & 8 & 2 & 10 & 2 & 10 & $10(25)$ & $37(92)$ \\
Teknonyms & 6 & 5 & 4 & 0 & 1 & 0 & 1 & 2 & $12(30)$ & $7(17.5)$ \\
Kin term & 0 & 0 & 0 & 0 & 0 & 0 & 0 & 0 & 0 & 0 \\
Endearment & 0 & 0 & 0 & 0 & 0 & 0 & 0 & 0 & 0 & 0 \\
Title & 2 & 0 & 2 & 1 & 6 & 1 & 6 & 1 & $16(40)$ & $3(7.5)$ \\
Occupation & 0 & 0 & 0 & 1 & 0 & 0 & 1 & 0 & $1(2.5)$ & $1(2.5)$ \\
\hline
\end{tabular}

However, the participants show alternative address terms in the workplace. Another common term of address used is Teknonyms. 30\% percent of the participants reported that they use forms like father of flaan or mother of flannah to address their superiors. The percentage of inferiors being addressed using first names by their superior is significantly lower (17.5\%). This could be attributed to the fact that an inferior attempts to show respect and build solidarity with their superiors. The lower percentage of using Teknonyms by superiors may indicate the desire to keep distance and maintain a certain degree of formality and hierarchy in the workplace. The data also show that men are inclined to use more teknonyms than women in the workplace. This may be because women are likely to be touchier about social status and hierarchy in the workplace.

Furthermore, proper titles are used by Saudi Arabic users to address each other in the workplace. Superiors are more likely to be addressed by titles such as ostathflaan, 'master X', and shaikh flaan. The data included a couple of instances of using double address terms consisting of the following structure: first term of address + the + second term of address. An example of this type is the use of Hadrat al mudeerah, 'the presence of the boss." This was reported only by female participants.

\subsection{Address Terms with Strangers}

One of the difficult situations in the use of address terms is addressing strangers because it is hard to identify the addressee's social status, relationship, and occupation. However, elicited data shows that Saudi Arabic speakers use various address norms in this situation. The physical appearance, age and job are important factors that determine proper address terms. The most common type is kin terms, distant kin terms in particular. Kin terms have been extended beyond the use for which they were coined. They are said to be used honorifically with both relative and non-relatives. In this context, they are highly used by the participants (72\%). They may be used to facilitate the process of interactions between strangers and promote solidarity among them, for example, words like $y a$ ? $a x$, 'hey brother,' as $y a$ is a vocative particle in case the speaker and the addressee are of the same age window. If there is an age-gap between them, other kin terms are used. That is, if the speaker is younger that the 
addressee, he is likely to use ya ?am, ya khal, ya khalah, 'paternal uncle, maternal uncle, aunt, respectively.' If the speaker is older than the addressee, the proper kin terms are ya waladi, ya binti, 'my son, my daughter, respectively.' Diminutive forms of kin terms are used when a very old speaker addresses a young person, for instance, ya wlaidi, 'hey my little son' and ya bnaiti, 'hey my little daughter.'

Table 7. Percentages/frequencies of address term usage with strangers.

\begin{tabular}{llllll}
\hline TOA & $\mathrm{M}+30$ & $\mathrm{M}-30$ & $\mathrm{~F}+30$ & $\mathrm{~F}-30$ & Total 40 (100) \\
\hline Common Name & 3 & 6 & 4 & 1 & $14(35)$ \\
Teknonyms & 2 & 1 & 0 & 0 & $3(7.5)$ \\
Kin terms & 8 & 6 & 8 & 7 & $29(72)$ \\
Titles & 4 & 5 & 1 & 0 & $10(25)$ \\
Endearment & 3 & 4 & 5 & 1 & $13(32.5)$ \\
Occupation & 1 & 0 & 0 & 1 & $2(5)$ \\
\hline
\end{tabular}

In addition, another frequently used term of address in strangers' context is common names. There are common names in the Islamic culture such as Mohammad, Ali and Hussain. Mohammad is the name of the prophet (peace be upon him), Ali is his cousin, and Hussain is the son of Ali. It is very common that people are named after these names and other famous names in Arabic and Islamic history. Fourteen percent of the participants reported their use of this type of names with strangers. The selection of these names is not arbitrary but rather it depends on the person's appearance, nationality and occupation. If a person is a young Saudi walking in the street, for instance, he is likely to be called Mohammad. If he looks like Yamani or works in occupation Yemenis are known for such as gas station, car mechanic, etc., he is likely to be called Hussain or Ali because these names are famous in Yamen. Other workers in small vocational jobs are called Mohammed. Workers from India, Bangladesh, Pakistan etc., are called Mohammad because their names are often difficult to pronounce. Thus, people give them famous names such as Mohammad.

Titles are also used to address strangers. A waiter or boss in a restaurant is likely to be addressed with titles such as Mu?alem, 'master.' If the worker is Egyptian, he is addressed with bashmuhandis, 'engineer.' Furthermore, terms of endearment are commonly used to address strangers including ya Sadiq 'friend,' ya habib, 'beloved' ya alghali, 'valued person.' These address types are used to facilitate interactions between participants, show respect and display solidarity.

\subsection{Zero Address Terms}

Interestingly enough, speakers of Saudi Arabic do not use address terms when they are in doubt of what term to use. They avoid this difficulty by using other greetings, attention getters, and prayers. They may use lao samaht, 'excuse me or hey!' They frequently use prayers such as ya? Teek ?al ?afiah, 'May God give health,' jazak Allah khair, ' May Allah reward you.' For example, an unknown bystander in the street may be stopped and addressed by Assalamu Alaiku, 'peace be upon you.'

\section{Conclusion}

This paper has provided a detailed analysis of a variety of address forms used in Saudi Arabic based on specific social factors and contexts. The researcher has examined the role of age, gender, social status and occupation in address term usage by using a questionnaire to elicit data. The results reveal nine main categories as fundamental techniques used by Saudi Arabic speakers to address one another. This category includes first names, Teknonyms, common names, kin terms, kin term along with first name, terms of endearment, titles, occupation and boy/girl. The frequency of each of these forms were examined in five different contexts; family, neighbors, school, workplace and strangers. Social factors such as age, gender, socio-economic status, level of formality as well as degree of intimacy and occupation were found to be essential in determining the use of these forms.

The findings indicate that, in family context, first name, kin terms and Teknonyms are the most frequently used address terms. Age and social hierarchy in the family determine the use of these terms. The diminutive form of the first names is used by older family members addressing younger members. The results report that close friend neighbors use first names, Teknonyms and kin terms because the relationships are already established. On the other hand, if the neighbor is non-intimate, Teknonyms, kin terms and terms of endearment are used more frequently. That is, the degree of intimacy between neighbors is a determining factor of address terms. The same holds true with non-intimate students addressing each other in school. That is, kin terms and endearment forms are commonly used. The social hierarchy, degree of formality, and qualification of the teacher influences the 
address terms between students and teachers. In the workplace, however, the hierarchy of the workplace impacts address term usage as first names are frequently used to address inferiors while superiors are addressed by Teknonyms and titles. Addressing strangers is governed by age, social status, occupation, and nationality of the addressee.

Further research may focus on the regional differences between speakers of different dialects spoken in Saudi Arabia. The small size of the sample and the use of questionnaire type of instrument may limit the results of this study. Future study may increase the number of participants and use more naturally occurring data to elicit more accurate results. The results of this study are delimited to speakers of Saudi Arabic and may not be generalized to other varieties of Arabic.

\section{Acknowledgement}

The author would like to thank the Deanship of Scientific Research at Majmaah University for supporting this work under project number (1440-140).

\section{References}

Afful, J. B. A. (2006). Non-kinship Address Terms in Akan: A Sociolinguistic Study of Language Use in Ghana. Journal of Multilingual and Multicultural Development, 27(4), 275-289. https://doi.org/10.2167/jmmd425.1

Al-Khatib, M. (2003). Address Norms in Jordanian Arabic: A Sociolinguistic Perspective. Grazer Linguistische Studien, 59, 1-20.

Al-Rabaa, S. (1985). The use of address pronouns by Egyptian adults. Journal of Pragmatics, 9, 645-657. https://doi.org/10.1016/0378-2166(85)90057-8

Bain, D., \& Dickey, E. (1998). Greek Forms of Address from Herodotus to Lucian. Phoenix, 52(1/2), 155. https://doi.org/10.2307/1088254

Braun, F. (1988). Terms of Address: Problems of Patterns and Usage in Various Languages and Cultures. New York: Mouton de Gruyter. https://doi.org/10.1515/9783110848113

Brown, P., \& Levinson, S. (1978). Universals in language usage: Politeness phenomena (E. Goody Ed.). Cambridge: Cambridge University Press.

Brown, R., \& Ford, M. (1961). Address in American English. The Journal of Abnormal and Social Psychology, 62(2), 375-385. https://doi.org/10.1037/h0042862

Brown, R., \& Gilman, A. (1960). The Pronouns of Power and Solidarity. Readings in the Sociology of Language, 252-275. https://doi.org/10.1515/9783110805376.252

Ervin-Tripp, S. M. (1972). On sociolinguistic rules: alternation and co-occurrence. In J. Gumperz \& D. Hymes (Eds.), Directions in Sociolinguistics (pp. 213-250). New York etc.: Holt, Rinehart and Winston.

Fargal, M., \& Shakir, A. (1994). Kin terms and titles of address as relational social honorifics in Jordanian Arabic. Anthropological Linguistics, 36, 240-253.

Geertz, C. (1972). Linguistic etiquette. In J. Pride \& J. Holmes (Eds.), Sociolinguistics (pp. 167-179). Harmondsworth

Jureidini, P., \& Maclaurin, R. (1984). Jordan: The impact of social change on the role the tribes. Washington D.C.

Keshavarz, M. H. (2001). The Role of Social Context, Intimacy and Distance in the Choice of Forms of Address. International Journal of Sociology of Language, 148, 5-18. https://doi.org/10.1515/ijsl.2001.015

Lambert, W. E., \& Tucker, R. G. (1976). Tu, vous, usted: a social-psychological study of address patterns. Rowley: Newbury, Laude-Cirtautas, IIse.

Mehrorta, R. R. (1981). Non-Kin Forms of Address in Hindi. International Journal of the Sociology of Language, 32, 121-137. https://doi.org/10.1515/ijsl.1981.32.121

Moles, J. A. (1974). Decisions and variability: The usage of address terms, pronouns and languages by Quechau-Spanish bilinguals in Peru. Anthropological Linguistics, 16(9), 442-463.

Oyetade, S. O. (1995). A Sociolinguistic analysis of address forms in Yoruba. Language in Society, 24, 515-535. https://doi.org/10.1017/S004740450001900X

Parkinson, D. B. (1985). Constructing the Social Context of Communication: Terms of Address in Egyptian 
Arabic. Mouton de Gruyter: Berlin, New York, Amsterdam. https://doi.org/10.1515/9783110857351

Sanda, S. (1993). The dynamics of honorific behavior in a rural community in Japan. Multi-lingua, 12(1), 81-94. https://doi.org/10.1515/mult.1993.12.1.81

Wardhaugh, R. (1992). An Introduction to Sociolinguistics. Oxford: Blackwell Publishers Inc.

Yule, G. (2006). The study of language. UK: Cambridge University Press.

\section{Note}

Biography, Aied Alenizi (PhD in Applied Linguistics, Ball State University) is assistant professor of linguistics. His major research interests include researching second language acquisition/studies, English language learning and pragmatics. He has worked on the acquisition of English articles by Arabic learners of English. Specifically, he investigated the extent to which EFL learners acquire the non-generic uses of the English definite articles and the relationship between English indefinite articles and noun countability. ORCID: https://orcid.org/0000-0001-9875-4668.

\section{Appendix A}

\section{Demographic Information:}

1) What is your nationality?

2) Where were you born?

3) What dialects do you speak?

4) Which of these dialects do you normally use?

5) How old are you?

6) What is your material status?

7) Are you male or female?

\section{1) Addressing Family members}

\section{a. How do you address members of your family?}

\begin{tabular}{l}
\hline \\
\hline Your father \\
Your mother \\
Your parents together \\
Your brother \\
(older than you) \\
Your brother \\
(younger than you) \\
Your sister \\
(older than you) \\
Your sister \\
(younger than you) \\
The father of your father \\
The father of your mother \\
The brother of you father \\
The sister of your father \\
The brother of your mother \\
The sister of your mother \\
Your son \\
Your daughter \\
The father of your spouse \\
The brother of your spouse (older than you) \\
The brother of your spouse (younger than you) \\
The sister of your spouse (older than you) \\
The sister of your spouse (younger than you) \\
Your spouse's father \\
Your spouse's mother \\
\hline
\end{tabular}


b. How are you addressed by your family members?

\begin{tabular}{l}
\hline BY \\
\hline Your father \\
Your mother \\
Your parents together \\
Your brother \\
(older than you) \\
Your brother \\
(younger than you) \\
Your sister \\
(older than you) \\
Your sister \\
(younger than you) \\
The father of your father \\
The father of your mother \\
The brother of you father \\
The sister of your father \\
The brother of your mother \\
The sister of your mother \\
Your son \\
Your daughter \\
The father of your spouse \\
The brother of your spouse (older than you) \\
The brother of your spouse (younger than you) \\
The sister of your spouse (older than you) \\
The sister of your spouse (younger than you) \\
Your spouse's father \\
Your spouse's mother \\
\hline
\end{tabular}

\section{Addressing Neighbors:}

a. How do you address a neighbor you know well?

\begin{tabular}{l}
\hline \multicolumn{1}{c}{ Terms of address } \\
\hline Younger than you \\
Same age as you \\
Older than you \\
Very young \\
Very old
\end{tabular}

\section{b. How do you address a new Neighbor you don't know?}

\begin{tabular}{ll}
\hline & Terms of address \\
\hline Younger than you & \\
Same age as you & \\
Older than you & \\
Very young & \\
Very old & \\
\hline
\end{tabular}

\section{c. How are you addressed by a neighbor you know well?}

\begin{tabular}{ll}
\hline & Terms of address \\
\hline Younger than you & \\
Same age as you & \\
Older than you & \\
Very young & \\
Very old & \\
\hline
\end{tabular}


d. How are you addressed by a new neighbor?

\begin{tabular}{ll}
\hline & Terms of address \\
\hline Younger than you & \\
Same age as you & \\
Older than you & \\
Very young & \\
Very old & \\
\hline
\end{tabular}

\section{At school}

a. How do you address a student whose name you know, and you don't know?

\begin{tabular}{ll}
\hline & \\
\hline Younger than you & Name Known \\
& Name unknown \\
Same age as you & Name Known \\
& Name unknown \\
Older than you & Name Known \\
& Name unknown \\
\hline
\end{tabular}

b. How are you addressed by a student whose name you know, resp. you don't know?

\begin{tabular}{|c|c|c|}
\hline & & Terms of address \\
\hline \multirow[t]{2}{*}{ Younger than you } & Name Known & \\
\hline & Name unknown & \\
\hline \multirow[t]{2}{*}{ Same age as you } & Name Known & \\
\hline & Name unknown & \\
\hline \multirow[t]{2}{*}{ Older than you } & Name Known & \\
\hline & Name unknown & \\
\hline
\end{tabular}

c. How do you address an instructor in class?

\begin{tabular}{l}
\hline Terms of address \\
\hline Younger than you \\
Same age as you \\
Older than you \\
\hline
\end{tabular}

d. How are addressed by instructor in class?

\begin{tabular}{ll}
\hline & Terms of address \\
\hline Younger than you & \\
Same age as you & \\
Older than you & \\
\hline
\end{tabular}

e. How are you addressed by an instructor outside class?

\begin{tabular}{ll}
\hline & Terms of address \\
\hline Younger than you & \\
Same age as you & \\
Older than you & \\
\hline
\end{tabular}

f. How are you addressed by an instructor outside class?

\begin{tabular}{ll}
\hline & Terms of address \\
\hline Younger than you & \\
Same age as you & \\
Older than you & \\
\hline
\end{tabular}


g. How do you address a professor in class?

\begin{tabular}{ll}
\hline & Terms of address \\
\hline Younger than you & \\
Same age as you & \\
Older than you & \\
\hline
\end{tabular}

h. How are you addressed by a professor in class?

\begin{tabular}{ll}
\hline & Terms of address \\
\hline Younger than you & \\
Same age as you & \\
Older than you & \\
\hline
\end{tabular}

i. How do you address a professor outside class?

\begin{tabular}{ll}
\hline & Terms of address \\
\hline Younger than you & \\
Same age as you & \\
Older than you & \\
\hline
\end{tabular}

j. How are you addressed by a professor outside class?

\begin{tabular}{ll}
\hline & Terms of address \\
\hline Younger than you & \\
Same age as you & \\
Older than you & \\
\hline
\end{tabular}

\section{2) At Work Place}

a. How do you address a subordinate?

\begin{tabular}{ll}
\hline & Terms of address \\
\hline Younger than you & \\
Same age as you & \\
Older than you & \\
\hline
\end{tabular}

b. How are you addressed by a subordinate?

\begin{tabular}{ll}
\hline & Terms of address \\
\hline Younger than you & \\
Same age as you & \\
Older than you & \\
\hline
\end{tabular}

c. How do address a peer?

\begin{tabular}{ll}
\hline & Terms of address \\
\hline Younger than you & \\
Same age as you & \\
Older than you & \\
\hline
\end{tabular}

d. How are you addressed by a peer?

\begin{tabular}{ll}
\hline & Terms of address \\
\hline Younger than you & \\
Same age as you & \\
Older than you & \\
\hline
\end{tabular}


e. How do you address a superior?

\begin{tabular}{ll}
\hline & Terms of address \\
\hline Younger than you & \\
Same age as you & \\
Older than you & \\
\hline
\end{tabular}

f. How are you addressed by a superior?

\begin{tabular}{ll}
\hline & Terms of address \\
\hline Younger than you & \\
Same age as you & \\
Older than you & \\
\hline
\end{tabular}

\section{3) Unknown Addressees}

a. How do you address a male/ female person you ask for information on the street?

\begin{tabular}{ll}
\hline & Terms of address \\
\hline Younger than you & \\
Same age as you & \\
Older than you & \\
Very old & \\
\hline
\end{tabular}

b. How are you addressed by a male/female person asks for information on the street?

\begin{tabular}{ll}
\hline & Terms of address \\
\hline Younger than you & \\
Same age as you & \\
Older than you \\
Very old
\end{tabular}

c. How do you address a policeman you ask for information on the street?

\begin{tabular}{l}
\hline \multicolumn{1}{c}{ Terms of address } \\
\hline Younger than you \\
Same age as you \\
Older than you \\
Very old \\
\hline
\end{tabular}

d. How do you address a male government official in his office?

\begin{tabular}{ll}
\hline & Terms of address \\
\hline Younger than you & \\
Same age as you & \\
Older than you & \\
Very old & \\
\hline
\end{tabular}

e. How do you address a waiter in a restaurant?

\begin{tabular}{ll}
\hline & Terms of address \\
\hline Younger than you & \\
Same age as you & \\
Older than you & \\
Very old & \\
\hline
\end{tabular}


f. How are you addressed by a waiter in a restaurant?

\begin{tabular}{ll}
\hline & Terms of address \\
\hline Younger than you & \\
Same age as you & \\
Older than you \\
Very old
\end{tabular}

g. How do address taxi driver?

\begin{tabular}{ll}
\hline & Terms of address \\
\hline Younger than you & \\
Same age as you & \\
Older than you & \\
Very old & \\
\hline
\end{tabular}

h. How are you addressed by a taxi driver?

\begin{tabular}{ll}
\hline & Terms of address \\
\hline Younger than you & \\
Same age as you & \\
Older than you & \\
Very old & \\
\hline
\end{tabular}

\section{Copyrights}

Copyright for this article is retained by the author, with first publication rights granted to the journal.

This is an open-access article distributed under the terms and conditions of the Creative Commons Attribution license (http://creativecommons.org/licenses/by/4.0/). 